\title{
Emozioen eragina erabakiak hartzean
}

\author{
Pello HuIZI
}

ILCLI (UPV/EHU)

\section{(The role of emotions in decision making)}

\author{
DOI: $10.1387 /$ gogoa.15636
}

\begin{abstract}
The aim of this paper is to study the role that is attributed at present to emotions in decision making. We make decisions constantly. Some of them are important, or very important, others not so much. When the outcomes are of great importance, one's desire to make a good decision is, of course, understandable. But the question is what people should do for that. Most of us were taught that, before we make a decision, we should examine the choices carefully and weigh up the pros and cons of each choice. Our decisions should be based on rational analysis of the choices, because we are logical beings. This is the idea we can find behind the philosophies of Plato and Descartes; modern economy is also based on the same idea, just like cognitive science's research for many decades. We have been defined as rational beings, rationality was what made us human. But, is it true? What's about the emotional side of human beings? Aren't we emotional as much as rational? Since Plato (and his metaphor of the chariot), most of the western thinkers agreed that emotions, at worst, hinder reason and, at best, are a harmless luxury. It is the negative view of emotions. About 35 years ago, however, the time of the positive view of emotions began. According to the positive view, if we want to behave reasonably and make good decisions, emotions are decisive.
\end{abstract}

Keywords: bounded rationality, decision-making, emotion, neuroscience, somatic marker.

Charles Taylor pentsalariak orain dela gutxi elkarrizketa batean esanak dira ondoko hitzak ${ }^{1}$ : «Filosofia hizkuntza, oso argia izan nahi duena, ez da

${ }^{1}$ Elkarrizketa El País egunkarian agertu zen 2015eko abuztuaren 11n; elkarrizketa Francesc Arroyok egin zion. 
nahikoa bizitzaren esanahi-mota ezberdinetan sakontzeko. Filosofoari dagokion eran hitz egin nahi bada, behar da irakurri literatura, behar da entzun musika, bai baitaude gauzak adierazteko beste modu batzuk.» Eta eransten $\mathrm{du}$ : «Filosofoaren diskurtsoak herren egiten du pixka bat literatura aintzat hartzen ez badu». Eta arrazoi hau ematen du: «Literaturan dagoen pentsamendu aberastasun eta trinkotasuna ezin da beste inolako testutan aurki$t u »^{2}$. Eta orain esan dezadan zergatik baliatu nahi izan dudan, Taylorrek hor filosofiaz esaten duenaz, lan honi hasiera emateko. Egia esan, elkarrizketa irakurri nuenean, oso egokia iruditu zitzaidan filosofoari buruzko gogoeta hori hemen aztertu nahi dudan gaia aurkezteko. Azaldu nahi dudana hauxe baita: gure pentsamendu arrazionala, edo, nahiago bada gure arrazoi hutsa, ez dela nahikoa hartzen ditugun erabakiak, gehienak behintzat, nola hartzen ditugun azaltzeko. Taylor-ek literatura eta musika jartzen dituen lekuan hemen emozioa jar daiteke. Edo, beharbada, egokiago litzateke esatea literaturak eta musikak, hor, gure arrazoibidean oro har eta gure erabaki-hartzean zehazkiago, emozioak duen eragina iradokitzen dutela. Aitor dezadan, bestalde, atseginez irakurri nituela pentsalari ezagunaren hitzak eta, beharbada, hori izan dela hona ekartzeko arrazoi nagusia. Bestalde, sentimenduek jarri dute martxan Xabier Arrazola zenari omenaldi hau eskaintzeko proiektua.

Lana $^{3}$ lau ataletan banatu da. Lehenbiziko atala erabaki-hartzeari eskaini zaio: horren garrantzi praktiko eta interes teorikoa, arlo horretan egin diren ikerketa-motak, eta erabakiak hartzeko jokabideari buruzko teoriak. Bigarren atalaren gaia emozioa izango da: emozioaren definizioaren inguruko arazoak, emozio-motak, eta emozioari buruzko ikusmoldeak historian zehar filosofian, psikologian eta ekonomian. Hirugarren atalean, lan honen helburua dena aztertuko da, hau da, zer egiteko edo rol aitortzen zaion orain emozioari erabaki-hartzean. Kontuan hartuko dira azken hiruzpalau hamarkadetako ekarpenak: neurozientziarenak, batetik, eta psikologoen esperimentuenak, bestetik. Azkenik, laugarren atal laburrean, emozioek erabaki-hartzean duten garrantzia nabarmentzen duten zenbait adituren iritziak aipatuko ditugu eta ondorioren bat atera, horrela lanari amaiera emanez.

\section{Erabakiak hartzea}

Lehen atala erabakiak hartzeko prozesuari eskainiko diogu. Erabaki-hartzearen estudioaren asmoa da ulertzea nola moldatzen garen aldian aldiko aukerak prozesatu eta irtenbide egokia hautatzeko. Oliveirak (2007) ohartarazten digu ez garela hasi berriak erabakiak hartzeko jokabidea aztertzen:

\footnotetext{
2 Charles Taylorrek ideia horiek azaldu zituen elkarrizketa egin zionak pentsalariaren obraren ezaugarri hau aipatu zuenean: filosofia testuez gainera, literatura testuak ere erabiltzea.

3 Oharra: Oin-oharretako testuen itzulpenak nireak dira.
} 
duela 300 bat urtetik ari omen da aztergai hau hainbat jakintza-arloren ekarpenak jasotzen. Hemen, atal honetan, honako puntu hauetaz emango dut azalpen bat edo beste: zein ohiko zaigun erabakiak hartzea, erabakiak hartzeko jokabidearen ikerketak, erabaki-hartzeari buruzko teoriak.

\section{Maiztasuna eta garrantzia}

Egunero hartzen ditugu milaka erabaki, aukeren artetik bat hautatzen dugun neurrian; erabaki batzuk ohartuz hartzen ditugu, ohartu gabe beste asko, gehienak beharbada. Horrelako zenbat erabaki hartzen ote ditugu, besterik gabe, etxetik lanera edo ikastetxera bidean? Erabaki batzuek ez dute garrantzi berezirik eta, horrelakoetan, egiteko erraza da erabakia hartzea; beste erabaki batzuk, ordea, gorabehera handikoak dira eta, orduan, gauzak korapilatu egiten dira. Erabaki bat hartzea funtsean zertan datzan adierazi nahi bada, badirudi hor bi gauza hauek sartzen direla: gertakari jakin batzuekiko usteak eta jendearen erreakzio subjektiboak gertakari horien aurrean (ikus, honetaz, Oliveira 2007). Erabakiak erantzunak dira, egoera batzuei ematen zaizkien erantzunak. Zeregin horretan hainbat prozesu kognitibok parte hartzen dute, hauek adibidez: dauden aukerak aztertzea, antzeko egoeretan zer egin izan den gogoratzea, hauta daitekeen aukera bakoitzak izan ditzakeen ondorioak. Prozesu kognitiboez gainera, kontuan izatekoa da, lan honetan azpimarratuko den bezala, prozesu emozionalen eragina. Egia esan, aipatu diren prozesu kognitiboetan beretan badute parterik emozioek.

Hona hemen erabakia hartzea zaila izan daitekeen adibide batzuk: zein karrera aukeratu, ezkondu ala ez, ezkontzekotan norekin ezkondu, non jarri bizitzen, hirian ala landetxe batean ... Dudarik gabe, azken hauek bezalakoak dituzte gogoan erabaki-hartzearen gaia axolarik handienekotzat jotzen duten autoreek. Horietako batzuen iritziak ekarriko ditut hona. Jonathan Evans psikologo kognitiboarena aurrena; honela dio: «Berealdikoak dira erabakihartzearen interes teorikoa eta garrantzi praktikoa ${ }^{4} »$ (Evans, 2007, 10 or.). Fuster neurozientzialariarena hurrena: «Erabakiak hartzeko askatasuna askatasunik preziatu eta garrantzitsuena $\mathrm{da}^{5}$ » (Fuster, 2014, 189 or.). Gilovich eta Griffin psikologo sozialek, berriz, honela hasten dute «Judgment and decision-making» izeneko beren lana: «Iritziak eratzea eta erabakiak hartzea jendeak egiten dituen gauzarik garrantzizkoenak dira ${ }^{6}$ (Gilovich \& Griffin, 2010, 542 or.). Azkenik, hona Marina (2011, 114 or.) ikertzailearen iritzia: «Oso handia da «erabaki-hartzeak» duen interesa. Horretaz ari dira psikolo-

\footnotetext{
4 «Decision making is of enormous theoretical interest and practical importance».

5 «La libertad para tomar decisiones es la más preciada y trascendental de todas las libertades».

6 «Making judgments and decisions are the most important things people do».
} 
gia, ekonomia, joko-teoria, eta baita «neuroekonomia» izeneko diziplina berria ere» 7 .

\section{Ikerketak}

Gaiaren garrantzi praktiko ukaezinak interes teorikoa piztu du, normala denez; eta hori, psikologian ez ezik, beste diziplina batzuetan ere bai: ekonomian, filosofian, soziologian, politikan eta, 1980ko hamarkadatik hona gutxienez, baita neurozientzian ere. Arlo honetako esperimentu psikologikoei dagokienez, jendeari egoera hipotetikoak aurkezten zaizkio eta eskatzen zaio hauta dezala eskainitako aukeren artean. Erabaki-hartzearen psikologiak badu teoria arauemaile bat, baita arrazionaltasunari buruzko eztabaida bat ere. Teoria arauemailea, ekonomiatik maileguz hartua, itxarondako baliagarritasunarena da.

Erabaki-hartzea aztertzeko esperimentuetan, psikologoek aukera arriskutsuen nahiz arriskurik gabekoen aurrean jar dezakete jendea. Psikologoak, noski, interesatuagoak daude erabaki arriskutsuetan. Hauetan, badaezpadakoak dira kontuan hartu beharreko aukerak. Ezin da jakin zein izango diren dauden aukeren emaitzak. Apustua pilotari edo pilotari-bikote baten alde egitea da erabaki arriskutsuen adibide bat. Galtzeko arriskua dago hor, baina baita irabazteko aukera ere. Horrelakoak dira bizitzak aurrean jartzen dizkigun aukera asko. Erabaki-teoria ekonomikoaren printzipio arauemaile nagusiaren arabera, erabaki hartzaileak itxarondako balioa maximizatzeko moduan egin behar du aukera. Erabaki-hartzearen ikerketa enpirikoek frogatu ahal izan dute erabaki-teoria arauemailea normalean ez dela betetzen. Aski izango da aipatzea Amos Tversky eta Danny Kahneman-en (1982; Kahneman, 2013) lanak eta berorien «heuristikoak eta isuriak» (heuristics and biases) paradigma.

Arriskutsuak edo arrisku gabeak izateaz gainera, erabaki-hartzea aztertzeko problemak atributu bakarreko nahiz askokoak eta fase bakarreko nahiz askokoak izan daitezke (Gilhooly, 1990). Atributu bakarreko problemetan atributu bakarrean desberdintzen diren objektuen artean hautatu behar da, bi diru-kopururen artean adibidez; nahiko erraza da hautatze-lana horrelakoetan, baina hautatze gehienak atributu askoko objektuen artean egin behar izaten dira. Horrelako kasuak dira, esate baterako, etxeak eta automobilak. Hemen, hautatzea zailagoa da, objektu bakoitzaren atributu garrantzitsuak aztertu, gogoan hartu eta konparatu behar direnez. Fase askoko problemetan egiten den aukera bakoitzak beste aukera sail baten aurrean jartzen

7 «La "toma de decisiones" interesa muchísimo. Se ocupan del tema la psicología, la economía, la teoría de juegos, incluso la nueva disciplina llamada "neuroeconomía"». 
gaitu. Adibidez, atera egingo naiz ala etxean geldituko? Ateratzea erabakitzen badut, nora joango naiz, zinera, museo bat ikustera, tabernara? Zinera joatea erabakitzen badut, zein film joango naiz ikustera? Bizitza errealeko erabakiak arriskutsuak, atributu askokoak eta fase askokoak izaten dira normalean.

Gilhoolyk bitan banatzen ditu erabaki-hartzearen ikerketak: arauemaileak eta enpirikoak. Lehenbizikoen helburua da ondorioak atera eta gomendioak egitea hartzen diren erabakiak arrazionalak eta ezin hobeak izan daitezen. Gogoan izatekoa da ekonomiaren ikuspegia izan dela luzaroan nagusi erabaki-hartzearen arloan. Eta ikuspegi horren atzetik uste hau zegoen, hots, gizakia animalia arrazionala dela eta bere onura optimizatzea bilatzen duela. Azken hamarkadetan psikologoek burutu dituzten ikerketa enpirikoak, ordea, ez datoz bat ikuspegi horrekin: jendeak ez ditu aukerak egiten teoria arauemailearen arabera.

Honaino esan denetik, baliteke irakurleak ondorio hau ateratzea: egiten diren ikerketetan ez direla kontuan hartzen jendeak bakarka hartzen dituen erabakiak baizik. Egia da, historikoki, ikerketa gehienek erabaki indibidualak aztertu dituztela. Baina gero eta gehiago hartzen da kontuan gizarte giroan bizi garela eta erabaki asko besteen begiradapean eta eraginpean hartzen ditugula. Rilling eta Sanfeyk (2011), adibidez, esaten digute erabaki garrantzitsuenetako asko testuinguru sozialean hartzen ditugula. Bestalde, erabaki askok eragina dute, ez guregan bakarrik, baizik baita beste batzuengan ere. Ez da harritzekoa, hortaz, erabaki indibidualak eta erabaki sozialak bereizi nahi izatea. Erabakietan testuinguru sozialak duen eragina ikertu nahi da erabaki-hartze sozialeko egitekoetan. Aipatu besterik egingo ez baditut ere, hona egiteko klasiko batzuk: Joko-teoria, Presoaren dilema, Fidagarritasun jokoa, Ultimatum jokoa eta Diktadorearen jokoa. Egiteko hauek erabiliak izan dira erabaki-hartze sozialaren alderdi batzuk ikertzeko, hala nola elkarrekiko trukea, justiziari eta ekitateari erantzutea, eta altruismoa eta zigorra. Paradigma berriak ere asmatu eta landu dira erabaki-hartze sozialaren beste alderdi batzuk aztertzeko, konformismo soziala eta ospearen kudeaketa adibidez.

\section{Teoriak}

Herbert A. Simonek (1983) Reason in human affairs liburuan eztabaidatzen dituen hiru teorien gainean ariko naiz hurrengo lerroetan. Erabaki-hartzeari dagokionez bada teoria berriagorik ere, Oppenheimer eta Kelsoren (2015) lanean ikus daitezkeenak esate baterako, baina hobe izango da hemen aipatuenak direnez zerbait esatea.

Simonek, esandako liburuan, arrazionaltasunaren hiru ikusmolde dakartza, erabaki-hartze arrazionalari buruz hitz egiteko hiru modu. Horietako lehenak, olinpiar eredua («the Olympian model») deitzen duenak, hautatze exhaustiboak egiten dituen gizaki heroikoa eskatzen du; bigarrenak, eredu 
behavioral edo jokabide ereduak, giza arrazionaltasunaren ikuspegi oso mugatua ematen du, mugak jartzen baitizkiote bai egoerak eta bai giza konputazio-ahalmen mugatuak ere; eta hirugarrenak, intuiziozko ereduak, intuizioprozesuak nabarmentzen ditu. Merezi du hiru teoria hauei arreta gehixeago eskaintzea.

Itxarondako onuraren teoria. Simonek olinpiar eredua esaten diona da, arrazionaltasunaren eredu klasikoa. Teoria honek eskatzen du, batetik, erabakitzaileak ezagutzea erabakiari dagozkion aukera guztiak, baita horien ondorio eta probabilitateak ere, eta, bestetik, ustekaberik gabeko mundu aurresangarri batean bizitzea. Baldintza horiek, ordea, oso gutxitan betetzen dira gizabanakoek nahiz taldeek ebatzi beharreko arazoetan (Simon, 1955). Simonek aitortzen du teoria hau kontzeptualki asmakizun ederra dela eta leku aukeratua mereziko lukeela Platonen ideien zeruan, baina, ziurtzat jotzen dituen usteak esplizituki adierazten direnean, garbi gelditzen dela ezinezkoa dela hori erabiltzea. Ezinezkoa da aukera guztiak, oraingoak eta gerokoak, ezagutzea, ezinezkoa horien probabilitateak kalkulatzea eta aukerarik onena zein den jakitera iristea; gizakiaren bizialdi osoa ere, bestalde, ez litzateke nahikoa izango teoriak eskatzen duen guztia egiteko. Simonek dioenez, teoria ez da behin ere aplikatu, ezta aplikatuko ere (1983). Nolanahi ere, erabakiak hartu, aukeren analisi arrazionalean oinarrituz hartu behar genituela irakatsi zitzaigun. Eta uste ere, hogeigarren mende ia guztian eredu ekonomikoek uste izan zuten, erabaki-hartzaileek horrela hartzen zituztela erabakiak. Orain dela 30-35 urte garunari buruzko aurkikuntza zientifikoak besterik erakusten hasi ziren arte. Garbi dago orain erabaki-hartze arrazionalaren ereduak ez duela egoki azaltzen aldian aldiko aukeren artean nola hautatzen dugun. Simonek, dena dela, aipatutako aurkikuntza zientifikoen aurretik ere, argi ikusi zuen eredu hau ez zela errealista.

Eredu behaviorala. Aurreko mendearen erdialdera beste eredu bat plazaratu zuen Simonek (1955): arrazionaltasun mugatuaren eredu behaviorala. Olinpiar ereduaren arrazionaltasunari, arrazionaltasun «mugagabea» edo «erabatekoa» dei daitekeenari (Gigerenzer, 2010), «arrazionaltasun mugatua» (bounded rationality) kontrajartzen zion. Arrazionaltasun mugatuaren ereduak alde batera uzten du arrazionaltasunaren teoriak optimizazioa nahitaezkoa duelako ideia. Arrazionaltasun mugatua (ikus, adibidez, Gigerenzer, 2010) jendeak erabakiak hartzean erabiltzen dituen prozesu kognitiboez ari da, emozioak barne. Gure arrazoitzeko gaitasuna mugatua denez, ordea, behar dugu mekanismoren bat arreta ipintzeko une jakin batean gure arreta eskatzen duten gauzetan. Simonek (1983, 21 or.) dio —eta psikologo fisiologoengan oinarritzen da hori esateko- «emozioen funtzio nagusietako bat arreta biltzea ${ }^{8}$ »

8 «The focusing attention is one of the principal functions of the processes we call emotions». 
dela. Geroago ere, 29. orrialdean, emozioaren funtzio hori azpimarratzen du, hau da, arreta jarri behar dugun gauzak aukeratzean datzana.

Intuiziozko arrazionaltasuna. Hirugarren eredu honi kasu gutxi egin diote zientzialari sozialek, Simonen iritziz. Hala ere, jendearen irudimenean leku nabarmenagoa duelako susmoa du berak. Eredu honen arabera, gizakiok erabaki zuzenak hartzen arrakasta badugu, horren arrazoia, neurri on batean, intuizio ona dugula da. Intuizioa «hara!» esperientziari dagokio, arazoaren irtenbidea bat-batean aurkitzeari. Simonek ez du kontraesanik ikusten intuiziozko ereduaren eta eredu behavioralaren artean. Bestalde, sarritan elkarri lotuak ikusten ditu intuizioa eta emozioa. Arazoaren irtenbidea urratsez urrats eta geldiro aurkitzeak nekez sortuko badu ere emozio bizirik, «hara!» esperientziak sarritan emozioa omen du lagun. Irtenbidea aurkitu duena harritu egiten da: hortik «hara!» esperientziaz hitz egitea. Intuizioak eta emozioak elkarrekin duten zerikusiaz ari dela, badu Simonek esaldi bat Jennifer S. Lerner eta honen lankideek (Lerner et al., 2015, 800 or.), horren garrantzia azpimarratu nahian, beren lanaren idazpuruan jarri dutena. Hona esaldia euskaraz: «Horregatik, giza arrazionaltasunaren teoria oso baten moduko zerbait edukitzeko, ulertu beharra daukagu zein den hor emozioaren rola.» ${ }^{9}$ Eta Lerner eta lankideek beren lanaren hasiera-hasieran diotenez, Simonek era horretan aitortzen zuen, emozioaren rola zehazten ez zen bitartean, bere teoria, bounded rationality delakoarena, osatu gabe egongo zela.

Eta, besterik gabe, pasa gaitezke lanaren hurrengo atalera, hain zuzen emozioari eskainiko diogunera.

\section{Emozioa}

Atal honetan, «emozioa zer den» galderari buruz egin diren hainbat gogoeta ikusiko ditugu aurrena. Ondoren, emozioaren eta erabaki-hartzearen arteko harremanak aztertzeko ikerketetan erabili izan diren emozio motak aurkeztuko ditugu, horietako bakoitzaren ezaugarriak azalduz. Azkenik, begiratu bat emango diogu historiari, ikusteko ea zer iritzi izan duten emozioari dagokionez filosofo, psikologo, ekonomista, moralista eta abarrek.

\section{Emozioa zer den}

«Zer da emozioa?» Aaron Ben-Ze'ev (2010) filosofoaren arabera, bai filosofoak eta bai psikologoak ere luzaroan obsesionatu dituen galdera omen

\footnotetext{
9 «Hence, in order to have anything like a complete theory of human rationality, we have to understand what role emotion plays in it» (Simon, 1983, 29 or.).
} 
da hori. Beste autore batzuek ohartarazten digutenez, Schererrek (2005) eta Fernández-Abascal eta Jiménez-Sánchezek (2010) adibidez, William James filosofo eta psikologo amerikarra izan zen galdera hori lehenbiziko aldiz egin zuena 1884an. Pisuzko erantzun bat eman nahi izan zion berak galderari, baina lortu zuena izan zen etengabeko eztabaida bati hasiera ematea. Orain ezin konta ahala erantzun daude, baina bat ere ez ikertzaile gehienek onartzen dutenik. Beraz, gaur egun ez dago adostasunik emozioen izaeraz. Filosofo askok, gainera, Dylan Evansek (2004) dioenez, dudan jartzen dute emozioaren definizio on bakar bat egon daitekeenik ere. Adostasun handiagoa biltzen du, nonbait, ideia honek: emozio hitzak biltzen dituen fenomenoak asko eta askotarikoak izateak eragotzi egiten duela definizio bakar batean denak bat etortzea. Damasiok (2010) ere emozionaltzat jotzen diren fenomenoen heterogeneotasunean ikusten du emozioaren ikerkuntzaren arazo handietako bat. Definizioarena bukatzeko, Evansek (2004, 188 or.) aipatzen duen Paul Griffits-en esaldi bat ekarriko dut hona: «emozio kontzeptu orokorrak ez du batere zereginik etorkizuneko inolako psikologiatan ${ }^{10}$.

Emozioaren definizio zehatza eztabaidagai da, hortaz. Hala ere, bada adostasunik zenbait puntutan, esate baterako emozioaren eta umorearen eta beste afektu orokorrago batzuen artean egin daitekeen bereizketari buruz (honetaz, ikus daitezke Basso eta Oullier, 2010; Baumeister, DeWall eta Zhang, 2007; Keltner eta Lerner, 2010; Petropoulou, 2006; Phelps, Lempert eta Sokol-Hessner, 2014; Zeelenberg et al., 2008). Keltner eta Lernerrek tasun emozionala, umorea eta emozioa bereizten dituzte. Tasun emozionalaz emozionalki erantzuteko estilo orokorra adierazten dute, aldi eta testuinguru desberdinetan irauten duena; normalean erantzuten den modua, hortaz. Umoreak emozioak baino gehiago irauten du eta ez dago hau bezain lotua kausa eta testuinguru jakin batzuei. Emozioak, bestalde, labur samarrak dira, une batekoak gehienetan eta aurreko biek baino lotura estuagoa dute kausa jakin batekin. Afektua eta emozioa bereizten dituzten autoreentzat afektua gaineko kontzeptua da eta kontzeptu horren barnean sartzen da emozioa, baita umorea eta sentimendua ere. Afektu hitzak, Lerner eta lankideen (2015) arabera, berriz, sentimendu zehaztugabeak adierazten ditu.

Emozioen ezaugarriei begiratzen badiegu, Ben-Ze'evek (2010) aldaketa jotzen du emozioen kausa tipikotzat: geure ingurunean, geure ingurune psikologikoan, aldaketa garrantzitsu bat sumatzen dugunean, orduan gertatzen da emozioa. Emozioak jakinarazten digu badela zerbait gure arreta eskatzen duena. Dena dela, aldaketa batek ezin du asko iraun. Hortik autore horrek berak emozioetan bereizten dituen ezaugarriak: egonkortasunik eza, intentsitate handia, partzialtasuna (hau da, helburua mugatua izatea, pertsona bat edo gutxi batzuk, adibidez), eta laburtasuna. Antzekoak dira Schererrek

10 «The general concept of emotion has no role in any future psychology». 
(2005) seinalatzen dituen emozioen ezaugarriak: aldaketaren lastertasuna, jokabidean eragina izatea, intentsitatea eta iraupena.

Emozioak direla eta, beste alderdi bat kontuan hartzen dena horien osagaiena da. Hélène Petropoulou (2006) psikologoak dioenez, gaur egungo autore gehienek hiru osagai bereizten dituzte emozioan: osagai fisiologikoa (erreakzio fisiologikoei dagokiena), jokabide-osagaia (jokabide eta adierazpen erreakzioei dagokiena) eta osagai kognitiboa (erreakzio kognitiboak biltzen dituena). Ben-Ze'evek, berriz, oinarrizko lau osagai aipatzen ditu; hauek: kognizioa, ebaluazioa, motibazioa eta sentimendua. Bi dimentsiotan biltzen ditu lau osagai horiek. Lehenbiziko hirurak intentzionala deitzen duen dimentsioan sartzen ditu; laugarrena, sentimenduaren dimentsioan. Osagai kognitiboak egoera jakin bati buruzko informazioa ematen du; zirrara bat eragingo badigu zerbaitek edo norbaitek, honi buruzko informazioren bat beharrezkoa zaigu. Ebaluazioaren osagaia informazio horri ematen zaion esanahi pertsonalari dagokio; osagai honek berealdiko garrantzia du emozioetan Ben-Ze'even arabera. Motibaziozko osagaiak egoera horretan zerbait egiteko nahia edo prestasuna adierazten du. Azkenik, sentimenduaren dimentsioari dagokionez, Ben-Ze'evek (2010, 49 or.) «kontzientzia modu primitibo bat ${ }^{11}$ » bezala ulertzen du eta gure egoerari lotua dagoela dio. Kontzientzia mailarik apalena izango litzateke.

Sentimendua dela eta, on izango da, puntu hau bukatu aurretik, aipatu bederen egitea Damasiok $(1994 ; 2010)$ egiten duen bereizketa emozioen eta sentimenduen artean. Emozioak ekintza-programak dira funtsean, gure gorputzean burutzen diren ekintzen programak; sentimenduak, aldiz, gure gorputzean eta gure gogamenean gertatzen denaren pertzepzioak dira, ekintzen irudiak ekintzak baino gehiago. Emozioak publikoak dira, sentimenduak ez, eta hauek haien ondotik gertatzen dira.

\section{Emozio-motak}

Emozioek erabaki-hartzean duten eraginaz ikerketek zer aurkitu duten ikusi aurretik — hori hirugarren atalean egingo dugu - komeni da emoziomota desberdin batzuk bereiztea. Autoreek bi galdera hartu dituzte kontuan berehala ikusiko ditugun emozio-motak bereizteko. Lehenbiziko galdera da noiz gertatzen den emozioa, erabakia hartzeko unean ala lehenago. Eta bigarrena da ea emozioak zerikusia duen erabakiarekin ala ez.

Lernerrek eta lankideek (2015) emozio integralak eta emozio intzidentalak bereizten dituzte. Emozio integralak erabaki jakin batekin berez zerikusia duten sentimenduak dira, hartu beharreko erabakitik sortzen direnak. Hona

11 «a primitive mode of consciousness». 
autore horiek jartzen duten ekonomiaren arloko adibidea: hainbat inbertsioren artean hautatu behar denean, hortik sortzen den dirua galtzeko beldurra. Emozio edo afektu ${ }^{12}$ intzidentalak, aldiz, erabakia hartzeko garaian gertatu arren, erabakiarekin berez zerikusirik ez duten sentimenduak dira. Esate baterako, inbertsioen artean hautatu behar duena gerta liteke une horretan urduri egotea ondoren hitzaldi bat eman behar duelako edo. Emozio intzidental batek eragin positiboa ere izan dezake, noski. Golemanek (1995, 85 or.) esaten duena horren adibide egokia da: «Umorearen aldaketa arinek ere eragina izan dezakete pentsamenduan. Planak egin edo erabakiak hartu behar dituenean, umore oneko jendeak badu hautemate-joera bat, modu irekiago eta positiboagoan pentsatzera eramaten duena» ${ }^{13}$.

Baumeisterrek eta lankideek (2007), izen desberdinak erabiltzen badituzte ere, antzeko bereizketa egiten dute. Uneko egoera emozionalak («current emotional states») eta emozio aurreratuak bereizten dituzte. Uneko egoera emozionalak erabaki hartzaileak erabakia hartzeko unean sentitzen duena adierazten du. Emozio aurreratuak, aldiz, esan nahi du pertsonak aurreikusi egiten duela zer sentituko duen erabaki jakin bat hartzen badu.

Loewensteinen eta Lernerren (2003) arabera ere, bi eratan parte har dezakete emozioek erabaki-hartzean. Lehen eragina itxarondako emozioak deitzen dituztenei dagokie eta honetan datza: aurreikustean zein izan daitezkeen erabakiaren emaitzen ondorio emozionalak. Itxarondako emozioak, hortaz, ez dira emozio gisa bizi erabakia hartzeko unean; geroago ustez sentituko diren emozioez ari dira. Bigarren eragina autoreek berehalako emozioak deitzen dituztenena da. Hauek erabakia hartzen den unean sentitzen diren emozioak dira. Bi era kualitatiboki desberdinetan eragin diezaiokete erabakiari: beren lana zuzenean egin dezakete, edo zeharka. Aurreneko kasuan, erabakiaren beraren ondorioak aurreikustetik datoz emozioak. Orduan berehalako emozioek autore hauek eragin aurreratuak deritzenak dituzte. Bigarren kasuan, erabakiarekin zerikusirik ez duten faktore batzuetatik sortzen dira emozioak, eta hauen eraginari eragin intzidentala esaten diote Loewenstein eta Lernerrek.

Puntu honetan ikusi duguna laburtuz, esan dezakegu funtsean bi emozio mota direla kontuan hartzekoak emozioaren eraginari dagokionez: emozio integralak, hau da, hartu edo ez hartu zalantzan gauden erabakitik beretik sortzen direnak, eta emozio intzidentalak, hau da, erabakiak ez baizik beste zerbaitek eraginak direnak.

\footnotetext{
12 Batzuetan afektu intzidentalaz hitz egiten dute, kontzeptu horretan, emozioa ez ezik, umorea ere sar daitekeelako.

13 «Even mild mood changes can sway thinking. In making plans or decisions people in good moods have a perceptual bias that leads them to be more expansive and positive in their thinking».
} 


\section{Emozioa historian zehar}

Emozioak luzaroan ospe txarra izan duela esateak ez du harrituko gaiari batere hurbildu izan zaiona. Ospe txarra filosofian eta ospe txarra psikologian (Frijda, 2008). Eta luzaroan: ehunka eta are milaka urtetan. Filosofiari dagokionez, Greziatik hasi behar, han sortu baitzen, duela 2.500 bat urte, xx. mendearen azken hamarkadak arte, mendebaldeko pentsamenduan nagusi izan den emozioen ikuspegi negatiboa, emozioak arrazoiaren etsaitzat hartzen zituena alegia. Eta ikuspegi negatibo hori dela eta, horri hasiera eman ziona aipatu behar nahitaez: Platon. Honentzat emozioak droga modukoak ziren, arrazionaltasuna itxuragabetzen zutenak. Ezaguna da Platonen orgaren metafora: gizakia (arima, zehazkiago) bi zaldik tiratua den orgazainarekin konparatzen zuen. Zaldietako bat ona eta ongi hazia da; bestea, aldiz, kontrolagaitza, baita orgazainik onenarentzat ere. Metafora horren bidez, Platonek bitan banatzen zuen gogamena, bi alderditan. Arrazoia eta emozioa dira, noski, bi alderdi horiek eta hauen arteko borroka bizi du arimak. Alderdi onena ateratzen bada nagusi, filosofiara daraman alderdia, orduan zoriontsua izango da gizakiaren bizitza; beste alderdia nagusitzen bada, aldiz, jende arruntaren bizitza egokituko zaio, emozioen mendeko eta filosofiarik gabeko bizitza. Fedro dialogoan azaltzen ditu Platonek ideia hauek (Platon, 2005). Berrogeita hamar urte geroago, Aristoteles kognizioa eta emozioa banantzearen kontra agertuko da eta horien arteko interakzioaren alde (Scherer, 2000). Dena dela, estoikoen artean ere nabarmena izango da emozioekiko mesfidantza, hauek arimaren gaixotasunak direla baitzioten.

Arestian aipatu dudan Fridjaren lanean irakurri dudanak harritu egin nau, ez baitut hori beste inon irakurri, baina ez dut hemen aipatu gabe utzi nahi: «Akinokoarentzat, emozio gehienak bekatu nagusien sailean ${ }^{14}$ » sartzen omen ziren (Fridja, 2008, 80 or.)

Descartes bat zetorren emozioen aspaldiko kritika horrekin. Berebiziko eragina izango zuen filosofo honek bitan banatzen zuen gizakia: arima, arrazoitzeko gai dena, batetik, eta gorputza, pasioz betea, bestetik. Helburu hau zuen Descartesek: agerian jartzea emozioek ilundu egiten dituzten ideia argi eta bereiziak. Kantentzat, bestalde, emozioek «gogamenaren gaixotasunak» adierazten zituzten (Fridja, ibid.). Eta, horrela, sentimenduak alde batera uztea eskatzen zuen haren inperatibo kategorikoak. Izan ere, sentimenduek, Kanten arabera, «kalte egin diezaiokete bidegabeki arauak aplikatzeari eta, arrazoia libre izanik, horren erabilerak kutsugabea izan behar $\mathrm{du}^{15}$ » (Marcus, 2002).

14 «For Aquinas, most emotions belonged to the capital sins».

15 «will bias the application of rules unfairly, and the use of reason, being free, must be uncontaminated». 
Gauzak bestela ikusten zituztenak ere izan dira filosofoen artean. Aipatu berria dugun Aristotelesez gainera, hemen leku berezia merezi dutenak Argien Mendeko filosofo hauek dira: David Hume, Adam Smith eta Thomas Reid. Dylan Evansek (2002, 11 or.) dioenez, «emozioek liluraturik zeuzkaten $^{16}$ » filosofo horiek. Emozioak gizabanakoarentzat ez ezik, gizartearentzat ere hil edo bizikoak ziren haien arabera. Ez zuten uste, inondik ere, emozioa eta pentsamendua elkarren etsai amorratuak zirenik; ildo berean, ulertezina iruditzen zitzaien gogoaren zientzia eraikitzen saiatzea bihotza alde batera utzita. Hona Marcus-ek (2002, 49 or.) probokatzailetzat jotzen duen Humeren baieztapena: «Arrazoia emozioen esklabo da, eta hori bakarrik izan behar du, eta ez du behin ere beste inolako funtziorik nahi izan behar haiek zerbitzatu eta obeditzea baizik ${ }^{17}$.» (Esaldi hau dela eta, ikus baita Lerner et al., 2015, 802 or. ere). Adam Smithek, bere aldetik, emozioaren psikologiaren oinarria ezarri zuen eta, batez ere, ekonomia abiarazi zuen jakintza gisa. Filosofo hauen pentsaerak eragin eskasa izan zuen filosofian, erromantikoek emozioen ikuskera zaharrari heldu baitzioten berriz, hau da, emozioen eta arrazoiaren artean borroka dagoelako ikuskerari. Ekonomian ere luzaroan ez da kontuan hartuko Smithen pentsamoldea.

Filosofiari dagokionez, Goldieren (2010) azalpenak hartuko ditugu kontuan gauzak orain dela gutxi arte nola izan diren eta orain nola eta zergatik aldatu diren ikusteko. Azalpen horiek The Oxford Handbook of Philosophy of Emotion liburuaren sarreran ematen ditu. 1960etako gogamenaren filosofiaren eskuliburuetan deus gutxi aurkituko omen da, ezer aurkitzen bada, emozioari buruz. Zergatik hori? Gogamenaren filosofia anglosaxoiaren ezaugarri batek esplikatuko omen luke hori; filosofia horrek jo izan omen du «emozioa beste gogo-egoera ezagunago (eta ustez hobeki ulertzen diren) batzuekin batera jartzera, uste edo nahi izatearekin batera adibidez, emozioaren 'sentitze' alderdia psikologoentzat utziz ${ }^{18}$ » (Goldie, 2010, 1 or.). Orain, dena dela, filosofoak interes handiz ari dira emozioa ikertzen eta fruituak ekartzen. Horren adierazgarri Goldie bera argitaratzaile duen eskuliburua da. Gauzak zergatik aldatu diren modu hain «dramatikoan» (berak erabiltzen duen hitzaz baliatzeko) azaltzen ere saiatzen da Goldie. Batetik, gero eta interes handiagoa dute gogamenaren filosofoek beste jakintza batzuetako lan enpirikoan: psikologia ebolutiboko eta antropologiakoan edo neurozientzietakoan, adibidez. Bestetik, gero eta jabetuago daude filosofoak emozioak arrazoi praktikoan duen garrantziaz. Beste arrazoi bat etikaren filosofiatik dator. Kant eta utilitarismoa nagusi ziren etikan emozioentzat ez zen lekurik; orain, Aristote-

\footnotetext{
16 «se sentían fascinados por las emociones».

17 «Reason is, and ought only to be the slave of the passions, and can never pretend to any other office than to serve and obey them».

18 «to assimilate emotion into other more familiar (and supposedly better understood) kinds of mental state such as belief and desire, leaving the 'feeling' side of emotion to the psychologists».
} 
lesen eta Humeren eta beste teorialari batzuen lanak kontuan hartzean, emozioak etikan duen garrantzia onartu da. Azkenik, filosofia estetikoa dela eta, artelanek, musikak edo literaturak esate baterako, guregan sortzen dituzten erantzunetan emozioak duen garrantzia nabarmentzen du filosofiaren arlo horrek.

Eta filosofiatik psikologiara. Ikus dezagun nolako tratua hartu duen emozioak psikologiaren historian. Psikologiaren hasiera hartan, Keltner eta Lernerrek (2010) psikologiaren fundatzaile ohorea aitortzen dieten Darwin eta James aipatu behar dira batez ere, emozioei ikerketa psikologikoan aitortzen dieten garrantziagatik. Gizakiek eta animaliek emozioak nola adierazten dituzten aztertzen duen Darwinen liburuak eragin handia izan du emozioaren psikologia modernoan (Scherer, 2000; Oatley, 1994). Antzekotasunak aurkitu zituen emozioen adierazpenean gizakien eta animalien artean, baita helduen eta haurren artean ere. Jamesek, bere aldetik, ideia hau defendatu zuen, Schererrek iraultzailea deitzen duena: emozioak gorputzeko aldaketen pertzepzioak direla. Schererrek berak dio (2000) Jamesen iradokizunak eragin gorabeheratsua izan duela emozioaren psikologian: bultzada eman zion, bai, orduko psikologian emozioaren gaineko eztabaidari, baina nahasketa iraunkor franko sortu ere bai.

Ondoren, 1920ko hamarkadan, behaviorismoa nagusitu zen, gogo-prozesuak baztertu eta arreta soil-soilik estimulu eta erantzunen arabera deskriba zitezkeen fenomenoetan jartzen zuena. Walden two bere liburu ezagunean Skinnerrek (1962/1948, 102 or.) dio emozioak «alferrikakoak eta gure gogo-baretasunarentzat kaltegarriak ${ }^{19}{ }$ direla. 1950eko hamarkadaren azken aldera kognitibismoaren aldia hasi zen, gogo-prozesuen azterketa zientzian sartzeko eskubidea aldarrikatzen zuena; baina gogamenaren teoria konputazionalak ez bide zuen leku egokirik aurkitzen eredu horretan emozioentzat eta hauek gogamenaren teorietatik kanpo geratu ziren. Beraz, badago esaterik, ia xx. mende guztian, arreta gutxi jarri zutela zientzialariek emozioen munduan. Eta kontuan izanik hemen emozioak erabaki-hartzean duen egitekoa dugula aztergai, ezin aipatu gabe utzi Lerner eta lankideen (2015, supplemental materials, 12 or.) oharra: «Psikologian, ez zen ia inoiz agertu emozioaren kausazko rolik erabaki-hartzean ${ }^{20}$ », eta hori, nonbait, horrela izan zen xx. mendearen gehienean.

Azken hogeita hamabost urte hauetan, ordea, gauzak asko aldatu dira arlo honetan. Keltner eta Lernerrek (2010, 312 or.) diote «emozioaren zientzia indartsu bat ${ }^{21}$ » sortu dela; Lerner eta honen lankideek (2015), berriz, emozioaren ikerkuntzan azken hamarkadetan gertatu den iraultzaz hitz egi-

\footnotetext{
19 «useless and bad for our peace of mind».

20 «In psychology, a causal role for emotion in decision making also hardly ever appeared».

21 «a robust science of emotion».
} 
ten dute. Bai Keltner eta Lernerrek eta bai Evans eta Crusek (2004) pizkunde horretan neurozientzialariei, Antonio Damasio eta Joseph LeDouxi bereziki, dagokien partea azpimarratzen dute. Evans eta Crusen (xi or.) arabera, emozioak orain «gaur-gaurko gaia dira ikerketa zientifikoarentzat ${ }^{22}$ ».

Emozioak historian zehar zer gorabehera izan dituen ikusten ari garen puntu honetan, ekonomiari ere eskaini behar diogu tarte bat; izan ere, ekonomia izan da historikoki erabakien teoria aztertzeari emana egon den diziplina akademiko nagusia. Gorago esan da nola XVII. mendearen erdi aldera Adam Smithek eta David Humek nabarmen jarri zuten emozioek duten eragina giza erabakietan. Hala ere, ia bi mende eta erdi behar izan dira ekonomia modernoak kontuan har zezan Argien Mendeko eskoziar filosofo horien intuizioa. Erabakien teoria tradizionalaren kritikak 1960ko hamarkadan hasi ziren, baina horietan ikusmolde kognitiboa zen nagusi, Loewenstein eta Lernerrek (2003) gogoratzen digutenez. Jendeak egiten dituen akats kognitiboak identifikatu nahi ziren, baita ezagutu ere zer heuristiko motaz baliatzen den jendea erabaki zailei aurre egiteko. Hemen sartzen dira, noski, Tversky eta Kahnemanen lanak. Lan aipatu eta goraipatu horiek, dena dela, ez zuten ia interesik jarri emozioek erabaki-hartzean duten zerikusian. Azken hamarkadetan psikologian eta neuropsikologian egin diren ikerketek eta hauek ekarri dituzten datu eta ezaguera berriek eragina izan dute ekonomian ere; ekonomistak, horrela, behartuak aurkitu dira onartzera emozioa kontuan hartu beharra dagoela aukerak nola egiten ditugun azaldu nahi bada. Hona, adibidez, Gneezy eta List (2014, 37 or.) ekonomia-irakasleek diotena: «Ekonomia

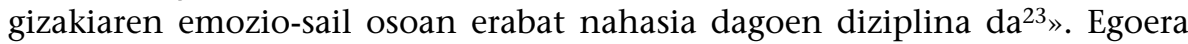
berriaren fruitua «neuroekonomia» da. Hau sortu da neurologoen interesa eta ekonomistei jendearen erabakiek jartzen dizkieten galderak elkartu edo gurutzatzetik; izan ere, inbertsore eta kontsumitzaileek ez baitituzte nahitaez hartzen teoria ekonomikoak ezartzen dituen erabakiak. Neuroekonomiari merezimendu hau aitortzen zaio: frogatu duela, zientifikoki frogatu ere, erabaki-hartzean emozioaren rola arrazionaltasunarena bezain garrantzitsua dela (ikus, honetaz, Reverchon, 2008).

\section{Emozioaren rola erabakiak hartzean}

Lehenbiziko atalean erabaki-hartzeaz aritu gara, horrek gure bizitzan duen garrantziaz eta horri buruzko ikerketa eta teoria batzuez. Bigarren atalean emozioa izan dugu mintzagai: horren definizio-arazoak, erabaki-hartzean duten eraginaren arabera bereizi izan diren emozio-motak, nola ikusi izan den

\footnotetext{
22 «a hot topic for scientific research».

23 «La economía es una disciplina completamente comprometida con todo el espectro de emociones del ser humano».
} 
emozioa historian zehar. Orain, aurreko bi ataletan ikusi ditugun bi gaien arteko harremanaz hitz egitea gelditzen zaigu, lanaren helburu nagusia dena, hasieran esan den bezala. Zer esan daiteke une honetan emozioek gizakiok hartzen ditugun erabakietan duten eraginaz edo rolaz? Zer erakusten dute orain arteko ikerketek? Azken atal hau bi azpi-ataletan banatuko dugu: lehenbizikoan neurozientziaren ekarpenak aurkeztuko ditugu eta bigarrenean esperimentu psikologikoen ekarpenak.

\section{Neurozientziaren ekarpenak}

Duela 25 bat mende Platonek irrika eta emozioen zaldia kontrolatzen zuen orgazainaren metafora asmatu zuenetik xx. mendearen azken hamarkadak arte, tradizio luze bat dago, arrazoia eta emozioa elkarren etsai bezala ikusi dituena. Ikusmolde hori neurozientziara aldatuko bazenu, zer esperoko zenuke? Seguru asko, hauxe: erabaki egokiak hartzea bekoki-lobulu arrazionalen esku dagoela, garuneko eskualde emozionaletatik sortzen diren instintuzko joerak kontrolatzen dituzten lobuluen esku, alegia. Baina gauzak oso bestela direla esan behar. Erabaki benetan egokirik ezin da hartu emozioek eskaintzen duten motibazioa eta esanahia gabe. Hori aurkitu zuen azpi-atal honetan protagonista izango dugun Antonio Damasio neurozientzialariak. Aipua luze samarra izango bada ere, merezi du berarengandik jakitea. Autoreak 1994an argitara emandako Descartes' error liburuaren 2012ko euskal itzulpenetik hartua da ondoko aipua (Damasio, 2012, 15-16 or.):

«Txikitatik esana zidaten erabaki zuhurrak buru hotzetik sortzen direla, eta emozioak eta arrazoia nahastezinak direla, olioa eta ura bezalatsu. (...) Guztiz hedatua zen arrazoiaren eta emozioaren arteko erlazioei buruzko pentsamolde hori, ikuspuntu mentalari eta neuralari dagokienez.

Baina, hara non, halako batean, imajina zitekeen gizakirik hotzena, emozioetatik askeena eta adimentsuena agertu zitzaidan begien aurrera, eta hara non gizaki haren arrazoimen praktikoa kalteturik ageri zen hala ere; hain kalteturik, ezen ezin konta ahala hutsegite eginarazten baitzizkion bizitzaren eguneroko hara-honakoetan, eta sozialki egoki eta norberarentzat abantailatsutzat joko litzatekeena behin eta berriro urratzera bultzatzen baitzuen. Gogamen erabat osasuntsua izana zuen lehenago, harik eta gaixotasun neurologiko batek garunaren parte espezifiko bat suntsitu eta egun batetik bestera erabakimeneko akats larri hura sorrarazi zion arte. Portaera arrazionalerako ezinbesteko eta nahikotzat jo ohi diren tresnak onik zeuden. Beharrezko ezagutza, arreta eta oroimenaren jabe zen; hutsik gabea zen haren mintzaira; gai zen kalkuluak egiteko; atzeman zezakeen problema abstraktu baten logika. Erabakimeneko akats haren eskutik arazo esanguratsu bakarra zetorren: nabarmen nahasirik zegoen sentimenak izateko gaitasuna. Arrazoimen akastuna eta sentimen suntsituak gailentzen ziren, beraz, garuneko lesio espezifiko haren 
ondorio gisa, eta bien arteko erlazio horrek zera iradoki zidan: sentimenak funtsezko osagai direla arrazoimenaren makinerian. Bi hamarkadaz, ikerketa kliniko eta esperimental ugari burutu ditut hamaikatxo neurologia-pazienterekin; behin eta berriro erakutsi didate ikerketok egitate hori, eta ideia hutsa zena hipotesi frogagarri bihurtu da».

Mundu guztian ezaguna den neurologoa dugu Damasio. Bekoki-lobuluen eta garunaren sakonean dauden emozioaren eskualdeen arteko harremana ikertu du. Erabakiak hartzeko gure gaitasuna handitzeko aztertzen ditu buruprozesuak.

Damasioren ikerketa lanaren abiapuntuan kasu historiko bat dago: Phineas Gage-rena. Hau, 1848ko irailaren 13an (urteaz gainera, hila eta eguna ere ezagunak dira), trenbidean lanean ari zela, istripu ikusgarri bat izan zuen. Lehergailua jarrita zegoen zulo bateko bolbora zapaltzen ari zen burdin barrak garezurra zeharkatu zion, begiaren azpitik sartuta. Harritzekoa bada ere, ez zen hil eta lesio iraunkorrik ere ez zitzaion gelditu; mugitzeko, pentsatzeko eta mintzatzeko gaitasunetan ere ez zuen aldaketarik jasan. Baina aldaketa Phineasen nortasunean gertatu zen, errotiko aldaketa, hura lehengo Gage zela sinesteak berak lagunei lanak emateko modukoa. Langile arduratsua eta hezibide oneko pertsona zena erasotzaile eta ezin aurreikusizko bihurtu zen.

Kasu horrek Damasioren jakin-mina piztu zuen eta egindako azterketak aurkikuntza honetara eraman zuen: Gagek garuneko eskualde bat, eskualde prefrontal bentromediala deitua, kolpatua zuela neurri batean. Damasioren ikerketen arabera, eskualde hori erabakigarria da erabakiak normal hartzeko. Garuneko kortex prefrontalean izandako lesioak kalte egin zien etorkizuna antolatzeko, gizarte-arauen arabera jokatzeko eta erabaki egokiak hartzeko Gage-ren gaitasunei.

Antzeko kasuak aztertu zituen Damasiok, istripuen edo kirurgia-operazioen ondorioz gertatuak. Horietako bat Damasiok «Elliott» deitzen duena da. Tumore bat zela eta neurokirurgia operazioa egin behar izan zioten eta garunaren parte bat galdu zuen, garun-azal orbitofrontala deritzana, bekokilobuluak emozioekin lotzen dituena. Operazioa arrakastatsua izan zen, nonbait, baina aldaketa handia gertatu zen Elliotten nortasunean. Besteak beste, Star Trek filmeko Spock jaunaren antzeko bihurtu zen, emozioz guztiz gabetua.

Kasu hauetan eta gainerakoetan gauza bera gertatzen zen beti: bekoki-lobulua emozioen eskualdeekin lotzen duten nerbio-bideak ebakitzean, pertsonak ezin ditu kontrolatu bere barruko bultzadak. Baina, hemengo gaiari dagokionez, bazen zerbait interesgarriagoa. Pertsona horiek arrazoitzeko gauza ziren, baina ez erabakiak hartzeko. Zergatik? Damasioren arabera, gaixo horien patologiak erakusten du erabakiak hartzeko prozesuan emozioak osagai erabakigarria direla. 
Antonio Damasioren lankideetako bat Antoine Bechara da, erabaki-hartzearen neurologiaren arloan lan ugari argitaratu dituena ikertzaile nagusi bezala, Damasio senar-emazteekin eta beste lankide batzuekin batera. Bada, Becharak (2012, 11 or.) honela laburtzen du kortex prefrontal bentromedialean min hartu dutenei gertatzen zaiena: buruan min hartu aurretik adimen normala zuten, min hartu ondoren ere bai. Baina orain arazoak dituzte eguneroko bizitzan erabaki onak hartzeko. Egiten dituzten aukerak ez dira orain onuragarriak, eta nabarmen desberdinak dira lehen egiten zituztenetatik. Aukera horietatik galerak ere segi daitezke, askotan gertatzen den bezala: galerak egoera ekonomikoan edo maila sozialean, bikotekideagandik banantzea, lagunengandik aldentzea eta abar. Beraz, gaixo hauen nahasmenduaren jatorria ez dago adimenean. Hala ere, kaltetua dute emozioak adierazteko gaitasuna eta eragozpen larriak dituzte erabakiak hartzeko orduan.

Erabakiak hartzeko eragozpen horren azalpen neural bat eman nahian, Antonio Damasiok (2012) «markatzaile somatikoaren hipotesia» proposatu zuen. Bechararen (2004, 30 or.) arabera, «hipotesi honen puntu nagusia da erabaki-hartzea emozioek bideratzen duten prozesua dela ${ }^{24}$ ». Zergatik izen hori? 'Markatzaile', dio Damasiok (2012, 256 or.), «irudi bat markatzen duenez» eta 'somatiko' «gorputzeko sentimen bat denez». Markatzaile somatikoen egitekoa zein izango litzatekeen honela azaltzen du Damasiok (ibid., 257 or.): «Markatzaile somatikoek ez dute gure ordez gogoeta egiten. Lagundu egiten digute gogoetan, aukera batzuk (arriskutsuak zein onuragarriak) nabarmenduz, ondorengo urratsetan jada aintzat har ez ditzagun». Beste era batean esateko, hemen aipatzen ari garen gaixoen erabaki egokiak hartzeko ezintasuna mekanismo emozional baten faltatik dator. Mekanismo hori somatikoa da eta berehala seinalatzen ditu ekintza baten ondorioak. Seinale hori falta zaienez, gaixo hauek dauden aukeren kostu-onuren analisia egitera jo behar dute, itxura gabe luza daitekeelarik analisia aukerak asko direnean. Baina, ez orduan bakarrik; aukerak bi baino ez direnean ere gerta daiteke hori. Damasiok (2012, 283 or.) berak kontatzen duen kasuan, adibidez. Bere laborategira hurrengo bisita noiz egin erabaki zezan bi data proposatu zizkion gaixoari. Hau agenda atera eta egutegia aztertzen hasi zen. Ordu erdi pasatxo egin zuen bi datetako bakoitzaren aldeko eta kontrako arrazoiak aztertzen. Azkenean, bigarren datan etortzeko esan zion Damasiok. Gaixoa, lasai «ongi iruditzen zait» erantzun, agenda gorde eta joan egin zen.

Markatzaile somatikoaren hipotesia egiaztatzeko Iowako joko ataza diseinatu zuen. Ataza lau karta sorta hauetaz osatua dago: A, B, C eta D. A eta B sortak txarrak dira, zeren, hasieran irabazi handia ematen badute ere, gero galtzea handiagoa baita; beraz, luzarora galtzea dakarte sorta horiek. C eta

24 «The main point of this hypothesis is that decision-making is a process guided by emotions». 
D sortak, aldiz, onak dira: berehalako irabazia apalagoa da, baina geroko galera txikiagoa; beraz, luzarora irabaztea dakarte. Parte-hartzaileek aukera egin behar dute lau karta sorta horien artean. Helburua da probetxurik handiena ateratzea maileguan ematen zaien joko-diruari, ahalik eta gutxien galtzen eta ahalik eta gehien irabazten saiatuz. Ataza honetaz baliatuz egin diren ikerketetan (Damasio, 2012; Bechara, 2004, 2012; Bechara, Damasio \& Damasio, 2000; Bechara, Tranel \& Damasio, 2000; Bechara et al., 1997), batez ere pertsona normalak eta paziente prefrontal bentromedialak konparatu nahi izan dira. Hona zer ikusi izan den: pertsona normalek A eta B sorta txarrak saihestu eta $\mathrm{C}$ eta $\mathrm{D}$ sortak hobesten dituzte; gaixoek, aldiz, saihestu ez, baizik nahiago dituzte sorta txarrak (A eta B).

Horrelako ikerketetan ikusi dena gaixo hauen eguneroko bizitzan gertatzen denaren bidetik doa: ez dute erabaki onuragarriak hartzeko gaitasunik aukera sari edo zigor berehalakoaren vs. atzeratuaren artean egin behar dutenean. Gauzak horrela, Damasioren inguruko ikertzaileen hurrengo galdera honako hau izan zen: "Zergatik dute paziente hauek «miopia» hori etorkizunari begira? ${ }^{25}$ » (Bechara, 2004, 32 or.). Horri erantzun ahal izateko, subjektuei, bai kontrol normalei eta bai paziente frontalei ere, aipatu berri den jokoa burutzen zuten bitartean neurketa psikofisiologiko bat egin zitzaien: larruazalaren konduktantzia erantzunen erregistroa. Erantzun hori, bai normalek eta bai pazienteek, guztiek sortzen zuten karta aukeratu eta dirua irabazi edo galdu egin zutela esan ondoren. Baina batzuen eta besteen arteko aldea nabarmena izan zen subjektu normalek egitekoan esperientzia lortu zutenean: azken hauek larruazalaren konduktzantzia erantzuna karta aukeratu baino lehenago sortzen zuten, hau da, karta zein sortatatik aukeratu hausnartzen ari ziren bitartean. Aurretiko erantzun horiek, gainera, nabarmenagoak ziren A eta B sorta arriskutsuetako karta bat aukeratu baino lehenago. Paziente prefrontal bentromedialek ez zuten era horretako inolako erantzunik sortu. Emaitza hauek, Bechararen (ibid., 32 or.) arabera, sendotu egiten dute «erabaki-hartzea emozio-seinaleek (edo egoera somatikoek) bideratzen dutelako ideia ${ }^{26}$.

Dena dela, azpi-atal hau bukatu aurretik, on izango da badaezpada eranstea hemen ohar hau: erabaki-hartzea emozioek bideratzen dutela esatean, ez Becharak ez Damasiok ez dutela inondik ere esan nahi emozioen lana beti onerako denik. Damasiok, adibidez, 1994an jada, Descartes' error liburuaren sarreran (Damasio, 2012, 17 or.), argi eta garbi adierazi zuen hori: «Hori esanik, ez dut ukatu nahi emozioek eta sentimenek egoera batzuetan hondamenik eragin ez dezaketenik arrazoitzeko prozesuetan. Jakituria tradizionalak erakutsi digu badutela eraginik, eta arrazoitze-prozesu normalari buruz

25 «Why do these patients have this «myopia» for the future?»

26 «strong support for the notion that decision-making is guided by emotional signals». 
berriki egin diren ikerketek ere agerian utzi dute kaltegarria izan daitekeela emozioaren bideratze-eragina». Becharak (2012), bere aldetik, dio emozioak noiz diren onuragarriak eta noiz kaltegarriak antzematea dela kontua. Eta hurrengo azpi-atalean agertuko den zerbait eransten du: emozioa mesedegarria da integrala denean, hau da, erabakiari berez doakionean, baina kaltegarria da zerikusirik ez duenean erabakiarekin.

\section{Psikologiaren ekarpenak}

Hasteko, begiratu azkar bat emango diogu emozioaren eta erabaki-hartzearen arteko harreman edo loturan psikologoek jarri duten arretari. Lernerrek eta lankideek (2015) beren lanaren hasieran ezarri duten irudia lagungarri gertatuko zaigu horretarako. Irudi horretan ikus daiteke nolako bilakaera izan duten, 1970etik hona, emozio/afektu/umorearen eta erabaki-hartzearen arteko harremanari psikologoek eskaini dizkioten argitalpen zientifikoek. Irudi horren aurrean, Lernerrek eta lankideek lehen egiaztapen hau ematen dute: arlo hau gaztea da; izan ere, 1970etik 2000ra arte ez dago ia argitalpenik gai horretaz. Baina, berehala, hau ere seinalatzen dute autore hauek: izugarri ari dela hazten arlo hau. Horren adierazgarri dira datu hauek: 2004tik 2007ra bitartean bikoiztu egin zen argitalpenen kopurua eta gauza bera berriz 2007tik 2011ra bitartean. Irudian sartzen den azken urtea 2013koa da eta 2011koen antzekoak dira 2012 eta 2013ko datuak.

Besteak beste, Herbert Simon eta Antonio Damasio eta honen taldearen lana aipatu behar dugu berriz hemen; horien ekarpenei zor zaie, segur aski, neurri handi batean, psikologoek arreta ipintzea emozioak arrazoimenean oro har eta erabaki-hartzean bereziki duen rolean. Lernerrek eta lankideek (2015, 800 or.) Herbert Simonen ekarpena aitortuz hasten dute beren berrikuspena: «Herbert Simonek iraultza abiarazi zuen erabakiaren teorian arrazionaltasun mugatua sartu zuenean ${ }^{27}$ ». Damasioren ikerketak eta berorren taldearenak ere oso aipatuak dira hemen kontuan hartuko ditugun lanetan. Baumeister eta lankideen (2007) ustez, Damasiok aztertutako paziente prefrontal bentromedialen kasua da emozioek erabaki-hartzea errazten dutela ongien erakusten duen adibidea.

Erabakietan duten eraginaren arabera bereizi izan diren emozio-moten berri eman dugu bigarren atalean. Orain emozio-mota horietako bakoitzak erabakiak hartzeko prozesuari nola eragiten dion ikusiko dugu.

Lernerrek eta lankideek (2015), esan bezala, bi mota bereizten dituzte: integralak eta intzidentalak. Gogora dezagun zer ulertzen duten autoreek emo-

27 «Herbert Simon launched a revolution in decision theory when he introduced bounded rationality». 
zio integralaz; erabakitzaileak orain hauta dezakeen aukerak berak sortzen duen emozioa da emozio integrala. Honen eragina gerta daiteke bai maila kontzientean, bai maila inkontzientean ere. Emozio integrala, Lernerren eta lankideen (ibid., 802 or.) arabera, «gidari mesedegarria ${ }^{28}$ » da, mendebaldeko pentsamenduan nagusi izan bada ere ikuspegi negatiboa emozioak arrazoian duen eraginari buruz. Dena dela, ez dute eskaintzen eragin onuragarriaren aldeko froga psikologikorik. Froga zientifiko pisudunak Damasiok eta honen taldeak aztertutako pazienteengan aurkitzen dituzte, emozioez gabetuak dauden horiengan. Emozio integralaren eraginez hartzen den erabakia egokiena ez den aukerara isuria edo lerratua ere gerta daiteke. Ematen duten adibidea da hegazkinean ibiltzeko beldurragatik autoz bidaiatzea erabakitzea, bidaiatzeko modu hau bestea baino arriskutsuagoa izan arren. Emozio integralen eragin mota hau oso iraunkorra da, nonbait, bestelako aukera baten aldeko informazio kognitiboa eskaini arren.

Emozio intzidentalak egoera batetik beste batera aldatzen edo eramaten diren emozioak dira eta eragina dute, berez, emozio horrekin zerikusirik izan beharko ez luketen erabakietan. Lernerrek eta lankideek (ibid.) lan ugari aipatzen dituzte emozio-mota honen eragina aurkitu dutenak. Adibide gisa, haserre intzidentalarena jartzen dute, egoera jakin batean piztu delarik, errua haserrearen jatorriarekin zerikusirik ez duten eta beste egoera batean aurkitzen diren pertsonei botatzea eragin dezakeena. Emozio intzidentalaren eragina aztertu nahian, 'balentzian' oinarritutako bidea hartu izan dute ikertzaile batzuek. Balentziak, hemen, esan nahi du emozioak bi kategoriatan banatzen direla: positiboak eta negatiboak. Lernerrek eta lankideek aipatzen duten Johnson eta Tverskyren (1983) ikerketa batean, parte-hartzaileek istorio batzuk irakurri zituzten umore positiboa edo negatiboa sortzeko pentsatuak eta gero bihotzeko gaixotasuna bezalako heriotza-kausa posible batzuentzat estimatu behar izan zituzten hildakoen maiztasunak. Bada, istorio negatiboak irakurri zituztenek, istorio positiboak irakurri zituztenek baino heriotzen estimazio pesimistagoak egin zituzten. Eguraldiak, edo inguruneko giroak, eta kiroletako emaitzek ere zerikusia badute jendearen bizi-pozean, jendeak berak adierazi duenez. Egun eguzkitsuetan jendearen poza eta zoriona handiagoa dela kontuan izanik, ekonomistek korrelazio positiboa aurkitu dute egun jakin bateko eguzki-argiaren eta burtsa-merkatuaren performantziaren artean. Beste adibide bat, aurrekoarekin zerikusia duena: herrialde bateko burtsa-merkatuko etekinak gutxitu egin omen ziren bertako futbol taldea Munduko Kopatik kanporatua gertatzearekin batera.

Baumeister eta lankideen (2007) lanak galdera honi erantzun nahi zion: emozioek mesede ala kalte egiten diote erabakiak hartzeko prozesuari? Hor dago, batetik, emozioek erabaki onak hartzea zaildu egiten dutelako ustea,

28 «beneficial guide» 
tradizio luzea duen ustea eta hor daude, bestetik, emozioek erabaki-hartzea erraztu egiten dutelako frogak, atal honetan ikusten ari garenak. Emozioak erabaki-hartzean duen eragina aztertzean, kontuan hartu behar direla diote autoreek zein emozio-motaz ari garen. Ikusi dugu gorago bi mota bereizten dituztela: uneko emozioak edo uneko egoera emozionalak eta emozio aurreratuak. Bereizketa hau garrantzizkoa dela diote autoreek. Zer gertatzen da, orduan, hauetako bakoitzarekin? Autoreen ustea da uneko egoera emozionalek mesede baino gehiago kalte egiten dutela. Emozio-mota honek eragina izango litzateke emozioek jokabide irrazionalari bide ematen diotelako herrijakinduria tradizionala. Emozioak ondorio suntsigarriak dituela adierazten duten frogetako asko ere mota honi egozten dizkiete autoreek. Adibidez, jendeak hartzen baditu erabakiak guztiz nahigabetua dagoela, edo erabat euforiko dagoela, gauza zentzugabeak egin ditzake eta erabaki irrazionalak hartu. Bestela dira gauzak - hala diote autoreek - emozio aurreratuen kasuan: hauen ondorioak mesedegarri gertatuko dira erabakiak hartzeko prozesuan. Gehienetan arrazoizkoa izango da honela hartzen den erabakia: lehenago bizi izandako esperientziak kontuan hartuz eta hautatzen denaren ondorioek sortuko duten emozioa aurreratuz, hau da, aurrez sentituz gero sentituko dena. Errudun sentitzearena eta damu izatearena aipatzen dituzte autoreek: ez bada aurrez errudun sentitzen, jendeak gizartearen edo moralaren kontrako ekintzak gauza ditzake. Era berean, ez bada aurreratzen aukera jakin bat egiteak damu izateko arriskua dakarrela, ondorioa tristura izan daiteke. Autoreek diotenez, beren lanean aipatzen dituzten zenbait esperimentuk frogatzen dute uneko emozioek gutxitu egiten dutela prozesaketa kognitiboa eta, horrela, kalte egiten diotela erabaki-hartzeari. Emozio hauek, batez ere negatiboak badira, jendea eraman dezakete luzaroan edukitako lehentasunak alde bat uztera berehalako atsegin bategatik. Esperimentu batean, adibidez, triste sentiarazitako subjektuek, normalek ez bezala, estrategia desegokia aukeratu zuten epe laburrean etekina lortzeko. Beste esperimentu batean ikusi zen jende tristeak beste batzuei lagundu, berak hobeki sentitzeko laguntzen zietela. Janari kaltegarri gehiegi jateko pertsona tristeen joera ere horrela jokatzeak beren umorea hobetuko duelako ustetik omen dator. Eta gauza berak balioko omen luke jokabide oldarkorrarentzat ere: pertsona haserreak eraso, hori eginez umorea aldatuko zaiola uste duenean bakarrik egiten omen du. Emozio aurreratuei buruz autoreek diotenetik, hau bakarrik jasoko dugu hemen: ordura arteko ikerketen arabera, 2007ra artekoen arabera hortaz, emozio aurreratuek uneko egoera emozionalek baino neurri handiagoan errazten dutela erabaki-hartze eraginkorra.

Loewenstein eta Lernerrek (2003) itxarondako emozioak eta berehalako emozioak bereizten dituzte, eta azkeneko hauen artean, eragin edo emozio aurreratuak eta eragin edo emozio intzidentalak. Itxarondako emozioak benetako emozioak baino gehiago, erabakiaren ondorioak ikusita sentituko denaren iragarpenak dira; beraz, kognizioak dira funtsean, geroko emozioari buruzko kognizioak. Itxarondako emozioek erabaki-hartzean duten rola dela 
eta, arriskupeko erabaki-hartzeaz ari diren teoriak arazo honen aurrean aurkitzen dira: jendeak nola egiten du aukera agian gertatuko ez diren emaitzen artean? Kahneman eta Tverskyren ikerketek agerian utzi zutenez (ikus, honetaz, Kahneman, 2013), jokoen ondorio posibleak ebaluatzean, jendeak ez du kontuan hartzen, itxarondako onuraren teoriak uste izango lukeen bezala, emaitza desberdinekin zein izango den azkenean geldituko zaion diru-kopurua, baizik zein izango diren irabaziak eta galerak. Esate baterako, $100.000 €$ dituenak $100 €$ galdu baditu ez da hasiko pozik dagoela esaten $99.900 €$ dituelako; seguru asko, kexatu egingo da $100 €$ galdu dituelako. Jendeak, bestalde, hartutako erabakien ondorioak askotan konparatzen ditu beste egoera batean gerta zitekeenarekin: autoreek «emozio kontrafaktualak» deitzen dituztenen kasua da. Bi emozio kontrafaktual seinalatzen dituzte: desengainua eta damu izatea. Emozio kontrafaktualen adibide bitxi bat 1992ko Olinpiar jokoetako domina-irabazleen gaineko ikerketatik dator. Loewenstein eta Lernerrek aipatzen dituzten Medvec, Madley eta Gilovich-ena (1995) da. Hona hauek aurkitu zutena: dominak jasotzerakoan, brontzezko domina irabazi zutenek, batez beste, poz handiagoa agertu zuten zilarrezko domina irabazi zutenek baino. Horren azalpena hau izan daiteke ikertzaileen arabera: brontzezko domina irabazi zutenek beheranzko konparazio kontrafaktualak egin zituzten («dominarik gabe geldi nintekeen»); zilarrezko domina irabazi zutenek, aldiz, goranzko konparazio kontrafaktualak egin zituzten («urrezko domina irabaz nezakeen»). Horrela, emozio kontrafaktualen eraginez irauli egin daiteke lorpen objektiboaren eta poztasun subjektiboaren artean espero daitekeen erlazioa. Dena dela, hemen esan beharra dago, desengainuak eta damu izateak eragina izateko erabaki-hartzeko unean, ez dela nahikoa erabakiaren ondorioak ikusi eta gero emozio horiek sentitzea; erabakia hartzerakoan eragina izateko erabakia hartzeko unera aurreratu behar dira eta, gainera, une horretan kontuan hartuak izan. Nolanahi ere, ikertzaileek uste dute damu izatea saihestu nahiak eragin handia izan dezakeela erabaki-hartzean. Itxarondako emozioei dagokiena labur daiteke esanez, batetik, jendeak emozioa sentituz erantzun, bere erabakien ondorio absolutuei baino gehiago dagoen egoerako aldaketa erlatiboei erantzuten diela eta, bestetik, gertatu dena gerta zitekeenarekin alderatzen duela, egoera kontrafaktualekin, alegia.

Loewenstein eta Lernerren (2003) arabera, berehalako emozioek, bi faktoreren eragina hartzen dute: eragin aurreratuena eta eragin intzidentalena. Aurreratutako edo aurrez hartutako erabakietatik orain sortzen diren sentimenduei esaten diete eragin aurreratuak. Erabakiaren ondorio negatiboetan pentsatzeak gehienetan emozio negatiboa sortzen du; ondorio positiboetan pentsatzeak, aldiz, sentimendu positiboa eragiten du. Eragin aurreratuei dagokienez, autoreek eztabaidatzen dituzten arazoetako batzuk honako hauek dira: probabilitateen eragina emozio-erreakzioetan (honetaz, ikus baita ere Baumeister et al., 2007), gogo-irudien eta batez ere irudi bizi eta afektuz kargatutakoen eragina egiten diren aukeretan. Irudi bizien kontua dela eta, adibidez, autoreek Johnson eta Tverskyk (1983) aurkitu zutena kontatzen dute: 
jendea prest zegoen aireko bidaiako aseguruagatik gehiago ordaintzeko «ekintza terroristek» eragindako heriotza barne hartzen zuenean heriotzakausa posible guztiak sartzen zirenean baino. Izan ere, ekintza terroristak oso erraz imajina daitezke. Erabakiaren eta horren ondorioen arteko denbora-tartearena ere aipatzen dute. Zenbat eta hurbilago dagoen parte hartzea erabaki den gertaera (jendearen aurrean kantatzea edo ipuin bat kontatzea, adibidez), orduan eta handiagoa izan daiteke beldurra eta urduritasuna, eta azkeneko unean jendeak uko egin diezaioke, zenbaitetan ikusi den bezala, parte hartzeari. Azkenik, eragin intzidentalen arloan norberaren berezko joerak edo bereizgarriak eragindako afektua eta egoerak eragindakoa bereizten dituzte. Ikerketek adierazten dute emozio-joera espezifikoek hautatzeko joera espezifikoak eragiten dituztela etengabe. Horrela, pertsona beldurtiek arriskuen ebaluazio pesimista samarrak egiten dituzte eta arriskuak saihesteko joera erakusten dute. Intzidentalak izan arren iraun egiten duten umore eta emozioek eragina dute egoerak eragindako afektuan. Haserreak, esate baterako, horren eragile izan denarekin zerikusirik ez duen hurrengo erabakia hartzerakoan, anbiguoa den jokabidea aurkakotzat hartzera eramaten du haserre jarraitzen duena. Bestalde, huskeria bat aski da eragina izateko egoerazko afektuan eta ondoren hartzen den erabakian. Horren frogagarri saltoki-gune batean egindako esperimentuan ikusi zena: usain atsegineko giroan jendea nabarmen prestago zegoen ikertzailearen lagun baten eskaerari erantzuteko halako usainik gabeko giroan baino.

\section{Konklusioa}

Greziako filosofoengandik hasi eta duela gutxi arte emozioen ikuspegi negatiboa izan da nagusi, ez bakarrik pentsalariengan, baizik baita literaturan eta herritar arrunten artean ere. Emozioen parte-hartzea erabakiak hartzeko prozesuan arriskutsutzat jotzen zen, arrazoiaren lana indargabe baitzezaketen. Azken aldi honetan, ordea, azken hiru edo lau hamarkadetan zehazkiago, ikuspegi positiboagoa zabaldu da. Neurozientzialariek frogatu dute ezin dela erabakirik hartu emozioen laguntzarik gabe. Hori hala izanik ere, indarrean jarraitzen du gorago aipatu dugun Baumeister eta lankideen (2007) galderak: «Emozioek hobetu ala zaikdu egiten dute erabakiak hartzeko prozesua? ${ }^{29}$ » Ikus ditzagun zenbait adituren iritziak. Eta aurrena Baumeister eta lankideena (ibid., 28 or.): «Emozioek rol garrantzitsua dute jendeak egiten dituen aukeretan ${ }^{30}$.» Berehala eransten dute, ordea, ikertzaileak ez datozela bat rol hori onerako ala kalterako den galderari dagokionez. Loewenstein eta Lernerrek (2003, 633 or.), mende luzeetan nagusi izan den

29 «Do emotions improve or hinder the decision making process?»

30 «Emotions play a significant role in the choices people make.» 
emozioen ikuspegi negatiboa aipatu ondoren, azken urte hauetako ikerketek azpimarratu dutena seinalatzen dute: batetik, «emozioek dituzten funtsezko funtzioak kognizioa eta jokabidea koordinatzen» eta, bestetik, «emozioak aintzat ez hartzeak dituen ondorio kaltegarriak ${ }^{31 » . ~ L e r n e r r e k ~ e t a ~ l a n k i d e e k ~}$ (2015, 816 or.), berriz, hara zer dioten: «Emozioak erabaki-hartzearen gidari indartsu, nonahiko eta aurresangarriak dira, batzuetan kaltegarriak eta beste batzuetan mesedegarriak ${ }^{32}$.

Emozioek, hortaz, funtsezko betekizunak dituzte erabaki-hartzean. Baina hautatze oker eta arriskugarrien eragile ere izan daitezke. Hartzen diren erabakietan emozio-mota ezberdinen eragina nolakoa den eta zergatik gertatzen den arazoan argi egiteko ikerketa gehiago behar da oraindik. Neurozientzia, psikologia eta ekonomia bezalako diziplinetako ereduak batera erabiltzea litzateke onena horretarako, dagoeneko abian diren saio batzuen bidetik. Laburbilduz, emozioek erabaki-hartzean duten eraginaren arloari garai batean arreta gutxi eskaini bazitzaion ere, orain diziplinarteko ikerkuntzaren bide berritzailea hartu duen arlo dinamiko bihurtu da.

\section{Erreferentzia bibliografikoak}

BASso, Fréderic et Oullier, Olivier (2010), « Le rôle des émotions dans la réalisation du processus de prise de décision ». In M. Amblard (arg.), La rationalité : Mythes et réalités. Paris : L'Harmattan.

Baumeister, Roy F., DeWall, C. Nathan \& Zhang, Liqing (2007), «Do emotions improve or hinder the decision making process» In K.D. Vohs, R.F. Baumeister \& G. Loewenstein (arg.), Do emotions help or hurt decision making? A hedgefoxian perspective. New York: Russell Sage Foundation Press.

BECHARA, Antoine (2004), «The role of emotion in decision-making: Evidence from neurological patients with orbitofrontal damage». Brain and Cognition, 55, 30-40.

BECHARA, Antoine (2012), The neurology of decision-making:: How neuroscience can enrich research on decision making. https://www.google.es/\#q=antoine+bechara+pdf (2015-10-09an jaitsia).

Bechara, Antoine, Damasio, Hanna \& Damasio, Antonio R. (2000), «Emotion, decision making and the orbitofrontal cortex». Cerebral Cortex, 10, 295-307.

Bechara, Antoine, Tranel, Daniel \& Damasio, Hanna ((2000), «Characterization of the decision-making deficit of patients with ventromedial prefrontal cortex lesions». Brain, 123, 2189-2202.

Bechara, Antoine, Damasio, Hanna, Tranel, Daniel \& Damasio, Antonio R. (1997), «Deciding advantageously before knowing the advantageous strategy». Science, 275, 1293-1294.

\footnotetext{
31 «the essential functions served by emotions in coordinating cognition and behavior» eta «the detrimental consequences associated with ignoring emotions».

32 «Emotions constitute potent, pervasive, predictable, sometimes harmful and sometimes beneficial drivers of decisión making».
} 
BEn-ZE'ev, Aaron (2010), «The thing called emotion». In P. Goldie (arg.), The Oxford Handbook of Philosophy of Emotion. New York: Oxford University Press, 41-62 or.

DAMASIO, Antonio (2012; 1994), Descartesen hutsegitea. Bilbo: ehupress.

DAMASIO, Antonio (2010), Y el cerebro creó al hombre. Bartzelona: Destino.

Evans, Dylan (2002), Emoción: La ciencia del sentimiento. Madril: Santillana.

Evans, Dylan (2004), «The search hypothesis of emotion». In D. Evans \& P. Cruse (arg.), Emotion, evolution, and rationality. New York: Oxford University Press, 179191 or.

Evans, Dylan \& Cruse, Pierre (2004), «Introduction». In D. Evans \& P. Cruse (arg.), Emotion, evolution, and rationality. New York: Oxford University Press, xi-xviii or.

Evans, Jonathan St. B.T. (2007), Hypothetical thinking: Dual processes in reasoning and judgement. Hove, East Sussex: Psychology Press.

FERnándeZ-AbasCal, Enrique G. eta Jiménez SÁnchez, Pilar (2010), «Psicología de la emoción». In E.G. Fernández-Abascal, B. García Rodríguez, M.P. Jiménez Sánchez, M.D. Martín Díaz eta F.J. Domínguez Sánchez (arg.), Psicología de la emoción. Madril: Ramón Areces, 17-74 or.

FrIJDA, Nico H. (2008), «The psychologist's point of view». In M. Lewis, J.M. HavilandJones \& L.F. Barrett (arg.), Handbook of emotions. New York, NY: Guilford Press.

Fuster, Joaquín M. (2014), Cerebro y libertad: Los cimientos cerebrales de nuestra capacidad para elegir. Bartzelona : Ariel.

GIGERENZER, Gerd (2010). «Moral satisficing: Rethinking moral behavior as bounded rationality». Topics in Cognitive Science, 2, 528-554.

Gilhooly, Kenneth J. (1990), «Decision making and judgement». In M.W. Eysenck (arg.), The Blackwell Dictionary of Cognitive Psychology. Oxford, UK: Blackwell, 89-93.

Gilovich, Thomas D. \& Griffin, Dale W. (2010), «Judgment and Decision Making». In S.T. Fiske, D.T. Gilbert \& G. Lindzey (arg.), The Handbook of Social Psychology ( $5^{\text {th }}$ ed.). Hoboken, N.J.: John Wiley \& Sons, 542-588.

GNeEzy, Uri eta List, John A. (2014), Lo que importa es el porqué: Los motivos económicos ocultos de nuestras acciones. Bartzelona: Urano.

Goldie, Peter (2010), «Introduction». In P. Goldie (arg.), The Oxford Handbook of Philosophy of Emotion. Oxford, N.Y.: Oxford University Press.

Goleman, Daniel (1995), Emotional intelligence. Broadway, N.Y.: Bantam Books.

Johnson, E.J. \& TVERsky, A. (1983), Affect, generalization, and the perception of risk. Journal of Personality and Social Psychology, 45, 20-31.

Kahneman, Daniel (2013), Pensar rápido, pensar despacio. Bartzelona: Debolsillo.

KeltNer, Dacher \& LerNer, Jennifer S. (2010), «Emotion». In S.T Fiske, D.T. Gilbert \& G. Lindzey (arg.), Handbook of Social Psychology. Hoboken, N.J.: John Wiley \& Sons.

Lerner, Jennifer S., Li, Ye, Valdesolo, Piercarlo eta Kassam, Karim S. (2015), «Emotion and decision making». Annual Review of Psychology, 66, 799-823.

LOEWENSTEIn, George \& LERNER, Jennifer S. (2003), «The role of affect in decision making». In R. Davidson, H. Goldsmith, \& K. Scherer (arg.), Handbook of Affective Science. Oxford, UK: Oxford University Press, 619-642 or.

MARCuS, George E. (2002), The sentimental citizen: Emotion in democratic politics. University Park, PA: Pennsylvania State University Press.

Marina, José Antonio (2011), Los secretos de la motivación. Bartzelona: Ariel.

Medvec, V.H., Madley, S.F. \& Gilovich, T. (1995), When less is more: Counterfactual thinking and satisfaction among Olympic medalists. Journal of Personality and Social Psychology, 69(4), 603-610. 
OATLEY, Keith (1994), «Emotion». In M.W. Eysenck (arg.), The Blackwell Dictionary of Cognitive Psychology. Oxford, UK: Blackwell, 129-134.

Oliveira, Arnaldo (2007), «A discussion of rational and psychological decision making theories and models: The search for a cultural - ethical decision making model». Electronic Journal of Business Ethics and Organization Studies, 12-2, 12-17 or.

OppenheIMER, Daniel M. \& Kelso, Evan (2015), «Information processing as a paradigm for decision making». Annual Review of Psychology, 66, 277-94.

Petropoulou, Hélène (2006), Profile émotionnel et cognitive au début de la sclérose en plaques : effets différentiels des émotions sur les performances cognitives. Psychology. Université Paris VIII Vincennes-Saint Denis.

Phelps, Elizabeth A., Lempert, Karolina M. \& Sokol-Hessner, Peter (2014), «Emotion and decision making: Multiple modularity neural circuits». Annual Review of Neuroscience, 37, 263-87.

Platon (2005), Fedon, Menon, Kratilo eta Fedro. Bilbo: KLASIKOAK.

REverchon, Antoine (2008). «Une approche séductrice». Le Monde: Économie. Mardi 15 janvier 2008.

Rilling, James K. eta SANFEY, Alan G. (2011). «The neuroscience of social decisionmaking». Annual Review of Psychology, 62, 23-48 or.

SCHERER, Klaus R. (2000), «Psychological models of emotion». In J.C. Borod (arg.), The neuropsychology of emotion. Oxford, NY: Oxford University Press, 137-162.

SCHERER, Klaus R. (2005), «What are emotions? And how can they be measured?». Social Science Information, 44(4), 695-729 or.

SIMON, Herbert A. (1955), "A behavioral model of rational choice». The Quarterly Journal of Economics, 69 (1), 99-118.

Simon, Herbert A. (1983), Reason in human affairs. Stanford, CA: Stanford University Press.

SkInNER, Burrhus F. (1962), Walden two. The Macmillan Company, NY: Macmillan Paperbacks.

TVERSKY, A. \& KAHNEMAN, D. (1982), Judgment under uncertainty: heuristics and biases. Cambridge: Cambridge University Press.

Zeelenberg, Marcel, Nelissen, Rob M.A., Breugelmans, Seger M. \& Pieters, Rik (2008), «On emotion specifity in decision making : Why feeling is for doing». Judgment and Decision Making, 3(1), 18-27 or. 